\title{
13
}

\section{The Sakkarra site: New data on prehistoric occupation from the Metal Phase (2000 BP) along the Karama drainage, West Sulawesi}

\author{
Suryatman, Budianto Hakim and Fakhri
}

\begin{abstract}
The Karama drainage supported the lifeways of prehistoric Austronesian speakers following their first arrival in Sulawesi. Beginning in 1935, early research along the Karama River brought to light various occupation phases related to the founding lineages and dispersal of Austronesian speakers within Southeast Asia's borders. More recent research indicates a Neolithic occupation phase between 3500 and 2500 years ago, after which time the Metal Phase began. The Metal Phase is fully demonstrated in the deposits of the Sakkarra site, on the Bonehau River in the southern Karama drainage, as described in this paper. Cultural developments associated with the Neolithic continued unabated into the Early Metal Phase, including the technology of polishing stone artefacts, which indeed appears to have been practised with enhanced skill.
\end{abstract}

Keywords: Karama drainage, Sakkara site, cultural development, Early Metal Phase

\section{Introduction}

Recent archaeological research confirms the scenario, originally developed from historical linguistics, that the Austronesian languages spoken almost universally by the indigenous inhabitants of Island Southeast Asia (ISEA) have their origins in mid-Holocene Taiwan. Austronesian speakers evidently migrated southward into the Philippines at around $4000 \mathrm{cal}$ BP and further south into Borneo and Sulawesi by $3500 \mathrm{cal} \mathrm{BP}$, as reflected at occupation and burial sites with a Neolithic technology that included earthenware pottery and polished stone adzes. Between 2500 and 2000 cal BP (the exact timing depending on area), the Early Metal Phase began, marked by the appearance of exotic items (especially from India) and the incorporation of metallurgy to complement the technologies introduced with the Neolithic (Bellwood 2017). As explained below, the Karama drainage opens an important window on this cultural sequence as it contains major habitation sites from both the Neolithic and Early Metal Phase.

The Karama drainage covers a large area that extends for a distance of $150 \mathrm{~km}$ from the highlands of West Sulawesi (Sulawesi Barat). Two main rivers mark the Karama drainage: the upper Karama, which originates from the east near the western range of Tanah Toraja Regency 
and flows past Kalumpang village; and the Bonehua, which runs for $43 \mathrm{~km}$ from the southern part of Mamuju Regency before draining into the Karama. These two rivers meet at a distance of $29 \mathrm{~km}$ from the Karama mouth, which lies on the Makassar Strait in the area of Sikendeng, Tarailu, Mamuju District (Figure 13.1). Research shows that the Karama drainage played a major role in the livelihoods of Austronesian speakers during their early occupation of the island of Sulawesi. This research, undertaken between 1935 and the present, has brought to light several sites with evidence relating to the occupation, dispersal and foundations of Austronesian speakers in the ISEA region.

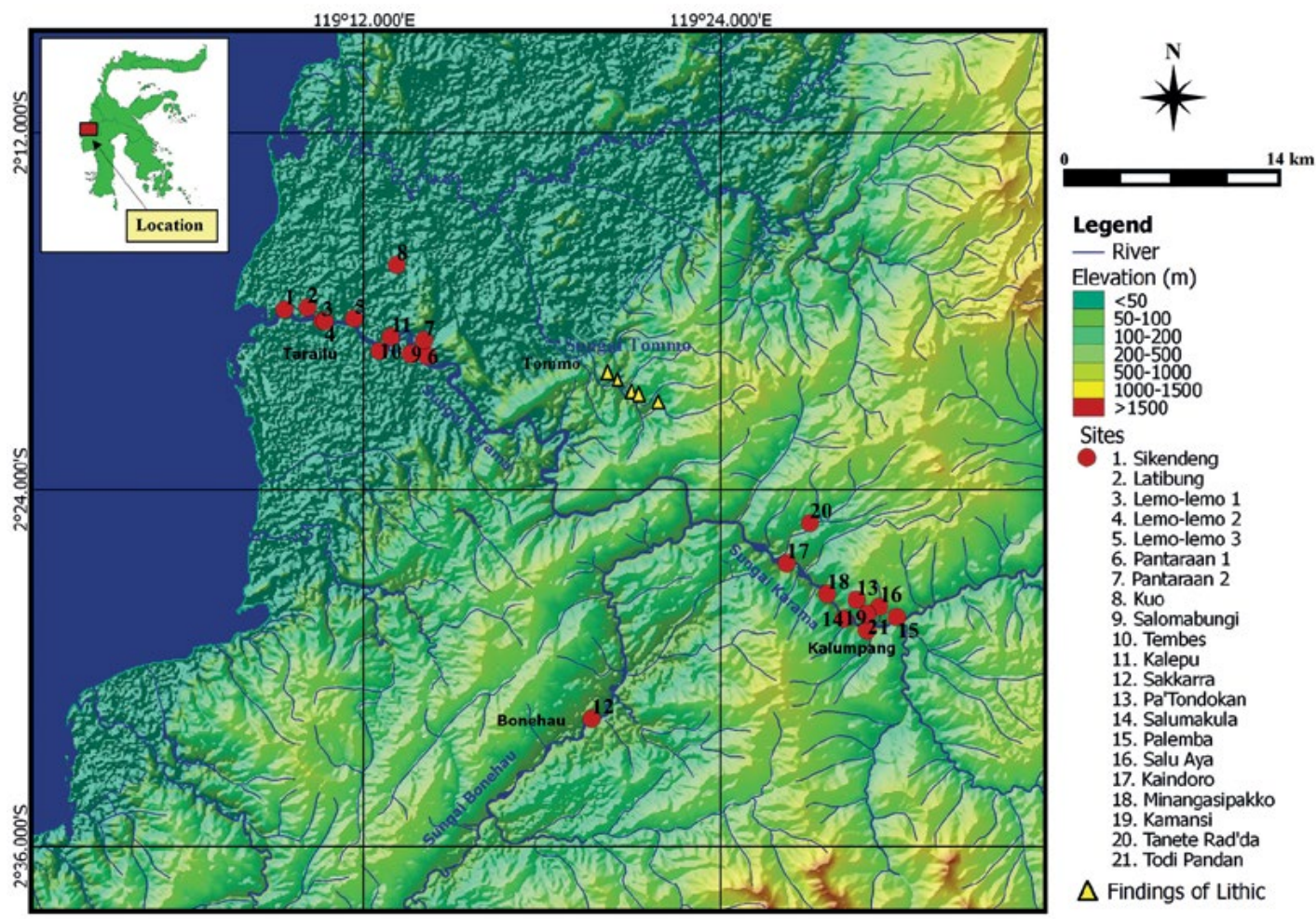

Figure 13.1: Map of the sectors and site locations along the Karama River drainage.

Source: Fakhri et al. (2015:Figure 1).

Kamansi (Kamassi) is a site on the upper Karama River, near Kalumpang. It was first excavated in 1937 by van Stein Callenfels, who recognised three occupation phases (van Stein Callenfels 1951). The first was the Proto-Neolithic phase, marked by edge-trimmed adzes, prototype shouldered adzes, Hoabinhian tools and primitive pottery. The second, Neolithic phase was marked by smoothly polished adzes and plain pottery. Finally, the third phase, the late Neolithic, was characterised by highly polished adzes, chisels and arrowheads, and decorated pottery. Van Stein Callenfels surmised that the first and third waves of occupants came from the Philippines, with Manchuria as the ultimate source in the case of the third wave. His work has led to a great amount of further research in the area, seeking to clarify these findings.

One such research effort was undertaken by Truman Simanjuntak in the Kalumpang region over multiple years (1994, 1995, 2004, 2007 and 2008), which also involved joint research projects with Australian archaeologists beginning in 2004 (Simanjuntak 1994; Morwood et al. 2007; Simanjuntak et al. 2007, 2008). Simanjuntak concluded that there were two Neolithic cultural phases at Kalumpang, particularly apparent at the Minanga Sipakko site. He described the first occupation phase, 3800-3000 cal BP, as being marked by red-slipped pottery and bone points. The following occupation phase, 3000-2500 cal BP, was marked by a change from red-slipped 
pottery to low-fired decorated pottery and the use of obsidian for making tools. The excavated deposits from both occupation phases also produced rectangular adzes and faunal remains (Simanjuntak 2015; Simanjuntak et al. 2007, 2008, 2016).

In 2011 and 2012, a team from the Makassar Archaeology Office returned to the Kamansi site to undertake excavations. This fieldwork indicated that the distribution of finds in the Kamansi and Minanga Sipakko sites were not very different. The basal layer produced red-slipped pottery associated with shell artefacts, adzes, stone bracelets and a decorated green-coloured stone. The upper layer produced coarse decorated pottery along with some obsidian flakes. The substantial increase in the quantity of pottery in the upper layer suggested a growing need for earthenware vessels (Hakim and Suryatman 2012).

Further research was performed by Anggraeni in 2012, including her excavation of the Pantara'an 1 site in the downstream stretches of the Karama drainage region. The available dates from char on potsherds were inferred to reflect Neolithic occupation from approximately 3000 to $2500 \mathrm{cal} \mathrm{BP}$. Interpretation of the archaeological sequence was complicated by the recovery of a jar, apparently associated with or used for holding a burial, placed in a hole dug through the habitation deposit into the sterile gravel below. Metal artefacts, beads and a bracelet of glass had been deposited in the burial jar, which accordingly would date to after $2500 \mathrm{BP}$, even though the metal and glass were recovered from a greater depth than the Neolithic habitation deposit (Anggraeni 2012; Anggraeni et al. 2014).

In 2014, a team funded by The Anthony F. Granucci Fund for Archaeological Research in Indonesia and Timor Leste returned to the Karama River drainage to collect further archaeological data (Fakhri et al. 2015). The surveyed area was divided into four sectors (Figure 13.1). The Tarailu sector was based near the mouth of the Karama, and data were collected from the Sikendeng, Latibung, Lemo-Lemo 1, 2 and 3, Kuo, Pantara'an 1 and 2, Salo Mabongi, Tembes and Kalipu sites. The Tommo sector along the north of the Karama drainage yielded various stone artefacts of limestone and chert. The Kalumpang sector to the east included various sites including Pattondokan, Salu Makula, Palemba, Kaindoro, Kamansi and Minanga Sipakko. Finally, an area along the southern border of the Karama drainage was labelled the Bonehau sector after a site with a high potential for prehistoric occupation was found there. This site, Sakkarra, is the focus of the present contribution.

\section{Description of the Sakkarra site}

The Sakkarra site is located in Bonehau village, Bonehau District, Mamuju Regency, West Sulawesi, Indonesia. The geographic coordinates are $02^{\circ} 31^{\prime} 42.0^{\prime \prime} S 119^{\circ} 19^{\prime} 40.1^{\prime \prime} \mathrm{E}$, and the elevation is 84 metres above sea level. The distance of the Sakkarra Site from Bonehau River is only $20 \mathrm{~m}$, whereas the Karama River lies $13 \mathrm{~km}$ away. It is an open site located about $1.3 \mathrm{~km}$ from the Talondo settlement and $1 \mathrm{~km}$ from the Mamuju-Kalumpang asphalt road. The land around the site is highly disturbed as it has been contracted as a gold mining area for five years. The land at the site is covered by shrubs and other secondary forest. A large portion of the site has been mined but operations have stopped because only a small quantity of gold was extracted.

The Sakkarra site (Figure 13.2) was found by the team in 2014 while surveying the Bonehau District, following local information of deposits rich with earthenware pottery uncovered during mining operations two years previously (Figure 13.3). About $20 \%$ of the site's surface had not been mined, and the parts that had been mined produced a thick coverage of earthenware sherds. Other finds on the surface include various adze fragments, glass beads, stone barkcloth beater fragments and various flaked stone artefacts (Figures 13.4 and 13.5a). Additionally, a stone adze was found by a local resident at the edge of a stream not far from the site (Figure 13.5b). 


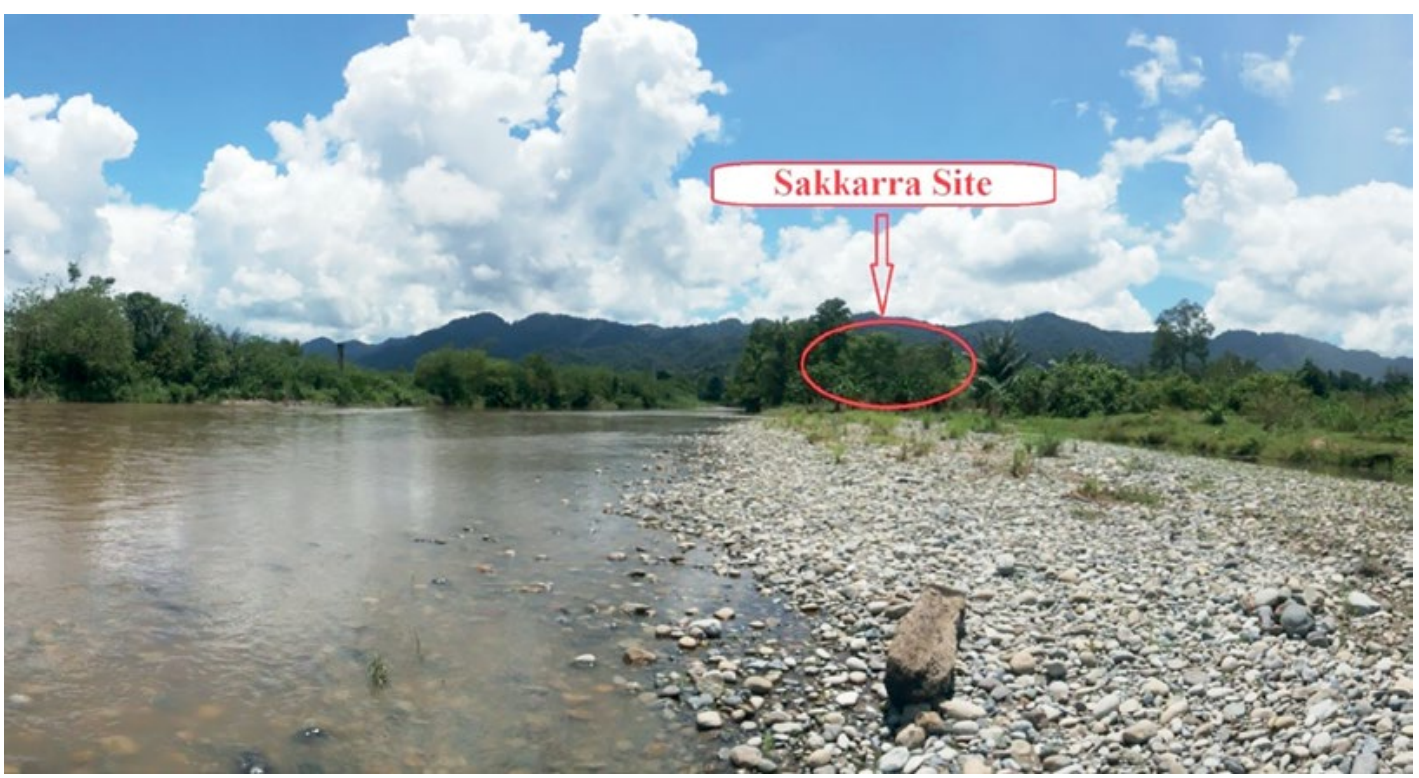

Figure 13.2: The Sakkarra site location on a hillock along the bank of the Bonehau River. Source: Fakhri et al. (2015:Figure 6).

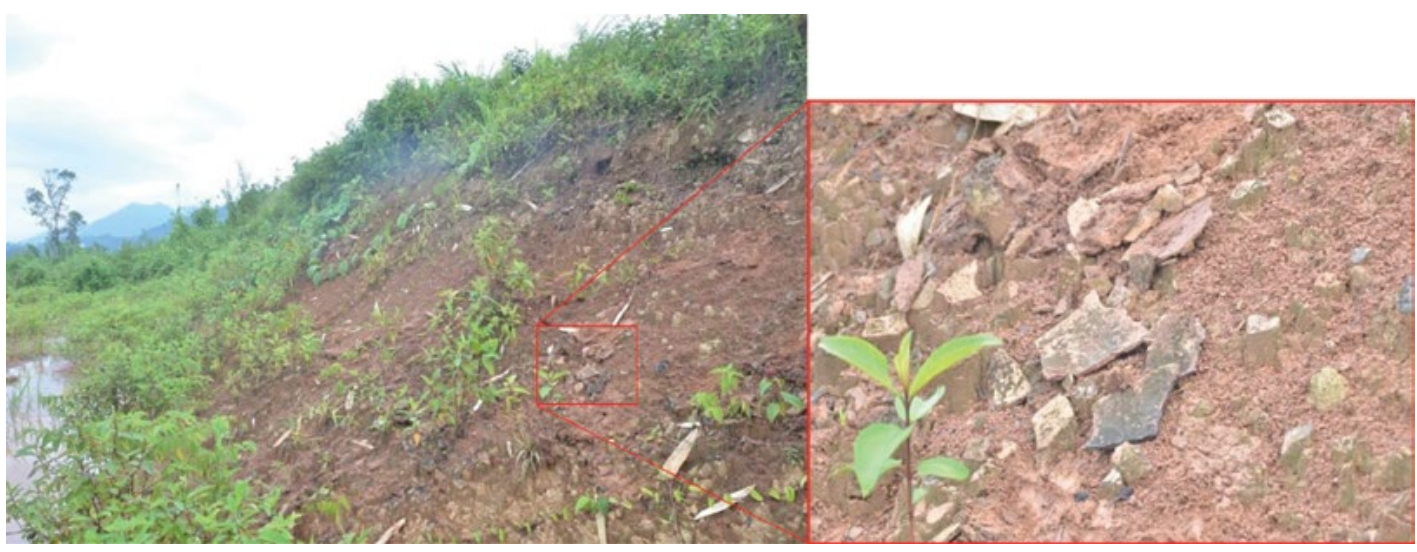

Figure 13.3: Exposure to a depth of 3 metres by mining activity (left), and an example of the earthenware sherds carpeting the mined area (right).

Source: The authors.

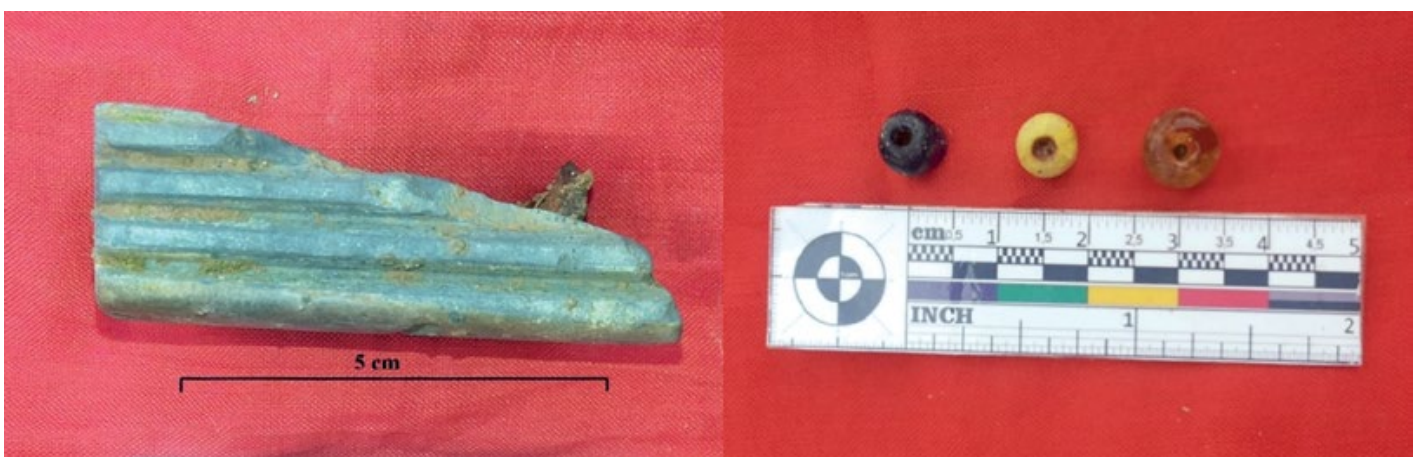

Figure 13.4: A barkcloth beater fragment (left) and glass beads (right) recovered from the surface of the Sakkarra site.

Source: Fakhri et al. (2015:Figures 8 and 9). 
a)
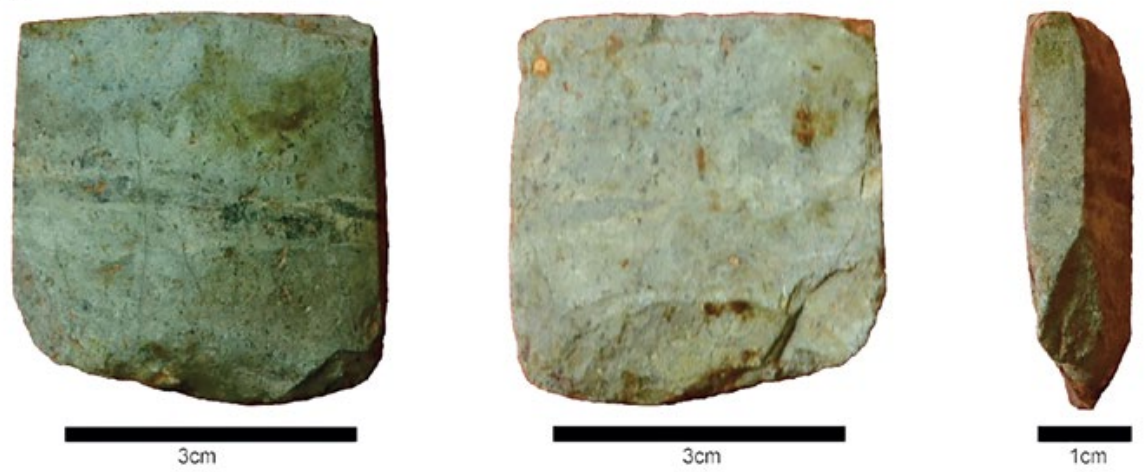

b)
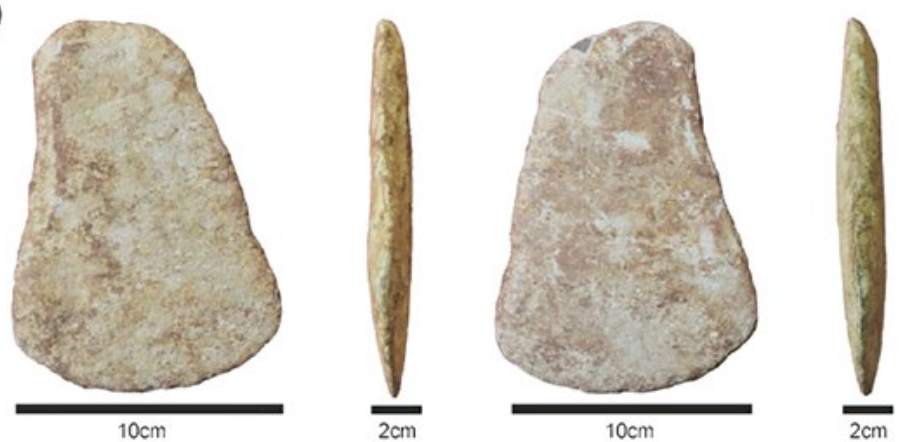

Figure 13.5: (a) Stone adze fragment found on the Sakkarra site surface, and (b) a stone adze found along the Bonehau River not far from the Sakkarra site.

Source: Fakhri et al. (2015:Figure 10).

\section{Excavation}

Excavation took place in 2014, three months after the discovery of the site. There were two excavation teams: a Makassar Archaeology Office team and a team funded by The Anthony F. Granucci Fund. Two test excavations were opened at a location that had not previously been disturbed through mining. The first excavation pit measuring $1 \mathrm{~m} \mathrm{x} 1 \mathrm{~m}$ was labelled kotak (square) T2S1, while the second excavation pit measuring $2 \mathrm{~m} \times 1 \mathrm{~m}$ contained kotak (squares) $\mathrm{B} 2 \mathrm{~S} 1$ and B3S1. Excavation proceeded using $10 \mathrm{~cm}$ spit depths; the deposit was removed, wet sieved in the adjacent stream and sorted on site (Figures 13.6-13.7).

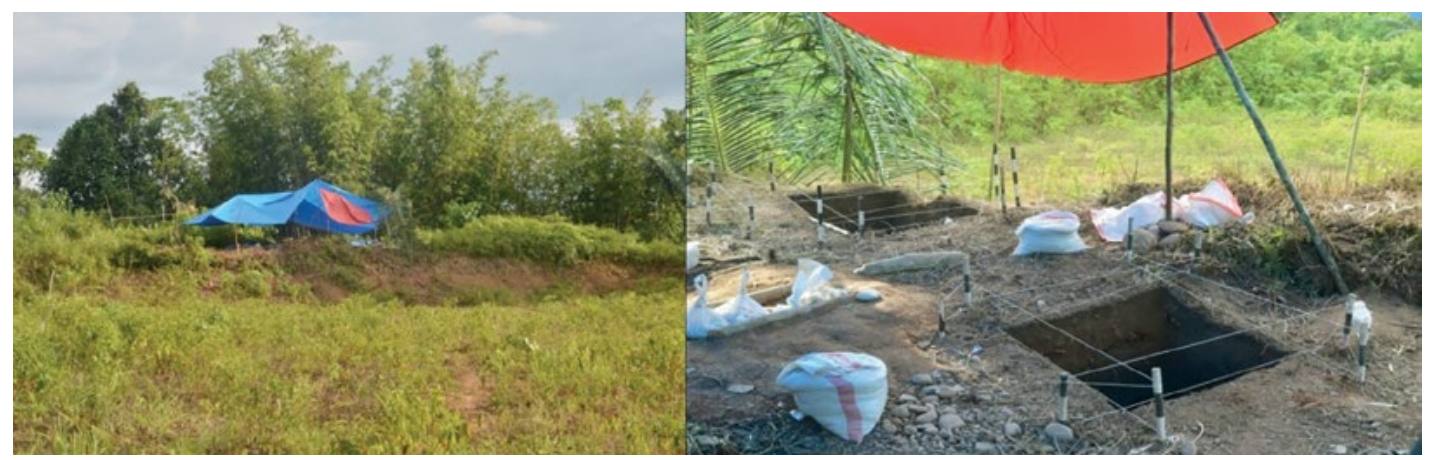

Figure 13.6: Location of the excavation squares at Sakkarra site.

Source: The authors. 


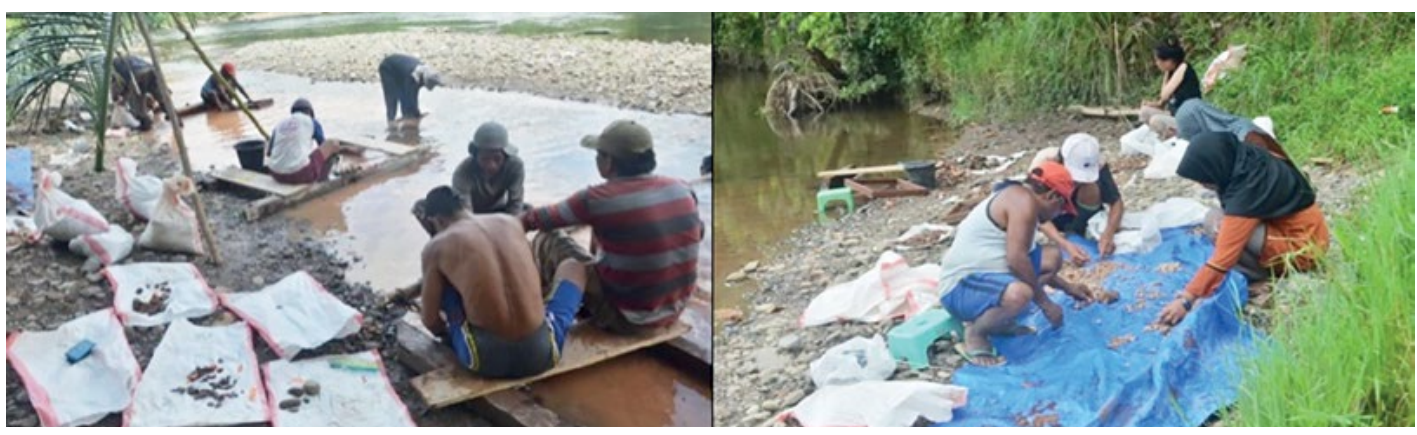

Figure 13.7: Wet sieving (left) and sorting (right) on site during the excavation of the Sakkarra site.

Source: The authors.

The T2S1 square was excavated to a depth of $2 \mathrm{~m}$ below the string line level, revealing a stratigraphy of four distinct layers (Figure 13.8). The top layer (Layer 1) was a very fine sand coloured dark brown (7.5YR 3/4). This top soil layer measured between 10 and $20 \mathrm{~cm}$ thickness with a maximum depth below the string line of $40 \mathrm{~cm}$ along the eastern wall. Layer 2 was a sandy clay that was dark yellowish-brown (10YR 4/6) in colour. It had a thickness of about $40 \mathrm{~cm}$ to almost $70 \mathrm{~cm}$ at its thickest part, which occurred on the north wall with a maximum depth of $86 \mathrm{~cm}$ below the string line. Layer 3 was a dark olive-brown silt $(2.5 \mathrm{Y} 3 / 3)$ that measured between $35 \mathrm{~cm}$ and $60 \mathrm{~cm}$ thick, reaching $125 \mathrm{~cm}$ below the string line on the north wall. The bottom layer (Layer 4 ) was a clay of olive-yellow colour (2.5Y 6/8), which continued through to the maximum excavated depth of $2 \mathrm{~m}$.

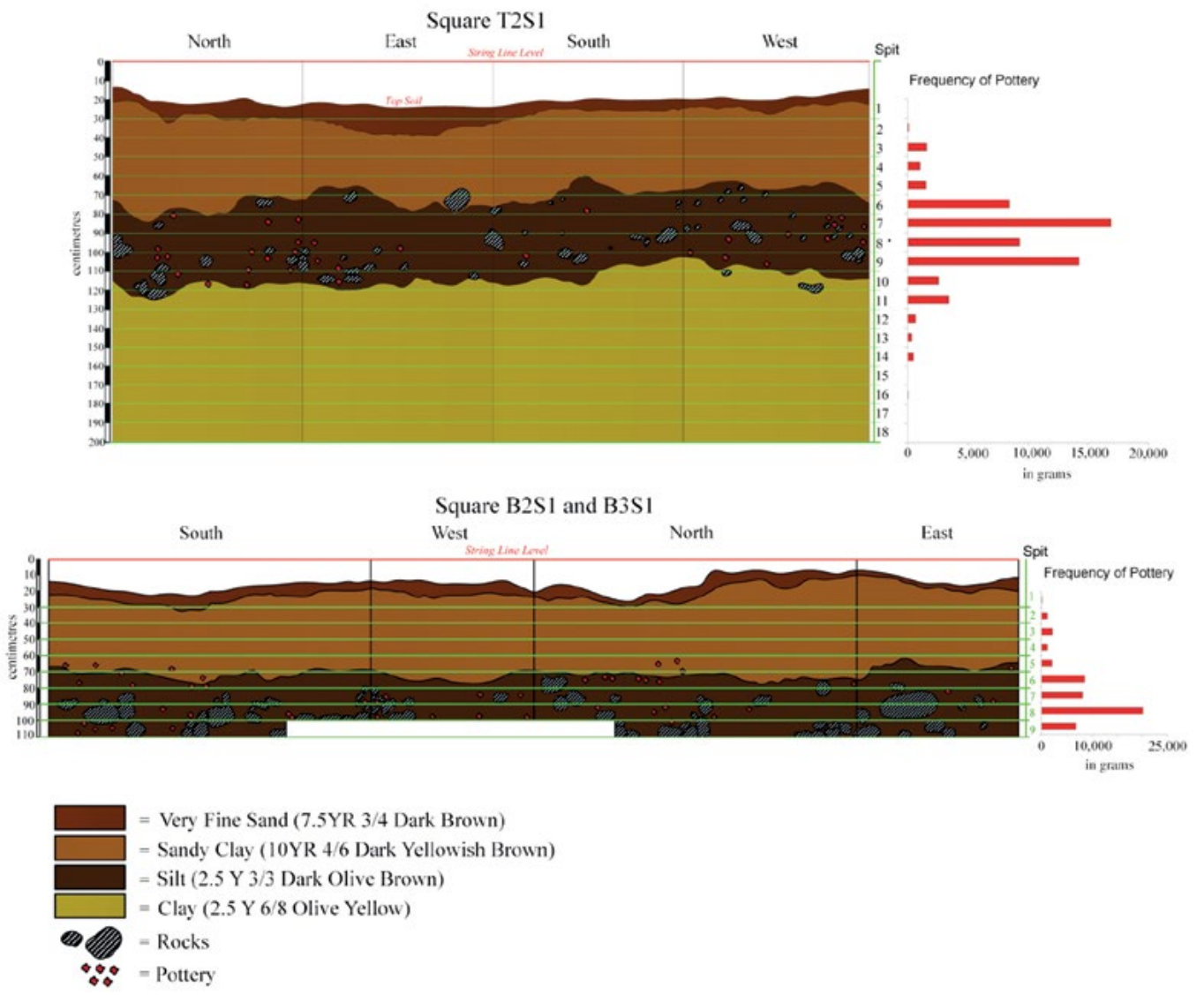

Figure 13.8: Stratigraphy of the excavated squares: T2S1 (above) and B2S1 and B3S1 (below). Source: The authors. 


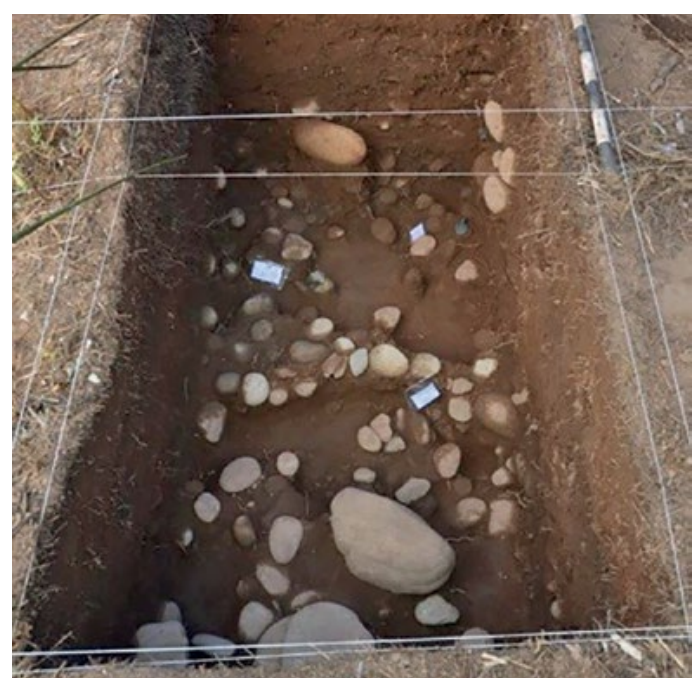

Figure 13.9: Layer of river boulders and cobbles at the floor of the B2S1 and B3S1 excavation squares. Source: The authors.
The B2S1 and B3S1 squares were excavated to the base of the Spit 9 at a depth of $110 \mathrm{~cm}$ below the string line level. The stratigraphy to that depth consisted of three layers with the same sedimentary characteristics as Layers 1-3 in T2S1 and similar layer thicknesses (Figure 13.8). The excavators decided to stop excavation at this level when they came upon a layer of river boulders and cobbles of volcanic stone that impeded further progress. This is an interesting finding as the stones are arranged like a pavement (Figure 13.9). Since the stones cover the clay-rich sediment lying beneath, perhaps they had been set in place to provide a walking surface on top of the underlying slippery sediment.

\section{Site analysis}

\section{Evidence of occupation}

Pottery sherds were recovered from most spits although, as shown in Figure 13.8, the highest concentrations of pottery fragments were found in the spits within stratigraphic Layer 3. In T2S1, the sherd weight was highest between Spit 6 (8454 g) and Spit 9 (14,218 g), with its peak at Spit $7(16,857 \mathrm{~g})$. In B2S1 and B3S1, the sherd quantity also increased markedly at Spit $6(8531 \mathrm{~g})$ before peaking at Spit $9(20,090 \mathrm{~g})$. Other finds also show that Layer 3 is the main occupation layer even though imported stoneware sherds were restricted to Layer 2 (Tables 13.1 and 13.2). Layer 3 cultural materials include iron slag (Figure 13.10), glass beads and glass bracelet fragments (Figure 13.11), a metal artefact, grindstones, stone adzes and a stone barkcloth beater fragment (Figure 13.12). Accelerator Mass Spectrometry (AMS) dates from charcoal samples taken from Layer 3 demonstrate that the period of occupation dates to approximately $2000 \mathrm{cal} \mathrm{BP}$ (Table 13.3). Fragments of bone were not recovered but this can be attributed to the strongly acidic nature of the deposit at the Sakkarra site $(\mathrm{pH}=4)$.

Table 13.1: Distribution of the excavated finds in the I2S1 square.

\begin{tabular}{|l|r|r|r|r|r|r|}
\hline Spit & $\begin{array}{c}\text { Earthenware pottery } \\
\text { (grams) }\end{array}$ & $\begin{array}{l}\text { Iron slag } \\
\text { (grams) }\end{array}$ & $\begin{array}{l}\text { Glass beads } \\
\text { (count) }\end{array}$ & $\begin{array}{c}\text { Stoneware sherds } \\
\text { (count) }\end{array}$ & $\begin{array}{c}\text { Glass bracelet } \\
\text { fragments (count) }\end{array}$ & $\begin{array}{c}\text { Ground stone } \\
\text { artefacts (count) }\end{array}$ \\
\hline 1 & 0 & 0 & 0 & 0 & 0 & 0 \\
\hline 2 & 120 & 56 & 0 & 0 & 0 & 0 \\
\hline 3 & 1618 & 0 & 0 & 2 & 0 & 0 \\
\hline 4 & 1031 & 0 & 0 & 1 & 0 & 0 \\
\hline 5 & 1549 & 0 & 0 & 0 & 0 & 0 \\
\hline 6 & 8454 & 145 & 0 & 0 & 0 & 0 \\
\hline 7 & 16,857 & 0 & 4 & 0 & 0 & 0 \\
\hline 8 & 9295 & 0 & 2 & 0 & 0 & 0 \\
\hline 9 & 14,218 & 428 & 1 & 0 & 0 & 5 \\
\hline 10 & 2590 & 86.5 & 0 & 0 & & 0 \\
\hline 11 & 3400 & 0 & 0 & & 0 & 0 \\
\hline
\end{tabular}




\begin{tabular}{|l|r|r|r|r|r|r|}
\hline Spit & $\begin{array}{c}\text { Earthenware pottery } \\
\text { (grams) }\end{array}$ & $\begin{array}{c}\text { Iron slag } \\
\text { (grams) }\end{array}$ & $\begin{array}{c}\text { Glass beads } \\
\text { (count) }\end{array}$ & $\begin{array}{c}\text { Stoneware sherds } \\
\text { (count) }\end{array}$ & $\begin{array}{c}\text { Glass bracelet } \\
\text { fragments (count) }\end{array}$ & $\begin{array}{c}\text { Ground stone } \\
\text { artefacts (count) }\end{array}$ \\
\hline 12 & 654 & 0 & 0 & 0 & 0 & 0 \\
\hline 13 & 328 & 0 & 0 & 0 & 0 & 0 \\
\hline 14 & 486 & 0 & 0 & 0 & 0 & 0 \\
\hline 15 & 0 & 0 & 0 & 0 & 0 & 0 \\
\hline 16 & 31 & 0 & 0 & 0 & 0 & 0 \\
\hline 17 & 0 & 0 & 0 & 0 & 0 & 0 \\
\hline 18 & 0 & 0 & 0 & 0 & 1 & 10 \\
\hline Total & 60,631 & 715 & 7 & 3 & & 0 \\
\hline
\end{tabular}

Source: Fakhri et al. (2015:Table 3).

Table 13.2: Distribution of the excavated finds in the B2S1 and B3S1 squares.

\begin{tabular}{|l|r|r|r|r|r|r|}
\hline Spit & $\begin{array}{c}\text { Earthenware } \\
\text { (grams) }\end{array}$ & \multicolumn{1}{|c|}{$\begin{array}{l}\text { Iron slag } \\
\text { (grams) }\end{array}$} & $\begin{array}{l}\text { Glass beads } \\
\text { count) }\end{array}$ & $\begin{array}{c}\text { Stone barkcloth beater } \\
\text { fragments (count) }\end{array}$ & $\begin{array}{c}\text { Glass bracelet } \\
\text { fragments (count) }\end{array}$ & $\begin{array}{c}\text { Metal artefacts } \\
\text { (count) }\end{array}$ \\
\hline 1 & 20 & 0 & 0 & 0 & 0 & 0 \\
\hline 2 & 1057 & 0 & 0 & 1 & 0 & 0 \\
\hline 3 & 2110 & 0 & 0 & 0 & 0 & 0 \\
\hline 4 & 1051 & 0 & 0 & 0 & 2 & 0 \\
\hline 5 & 2060 & 0 & 0 & 0 & 0 & 0 \\
\hline 6 & 8531 & 254.3 & 9 & 0 & 0 & 0 \\
\hline 7 & 8069 & 0 & 6 & 0 & 0 & 0 \\
\hline 8 & 20,090 & 0 & 1 & 0 & 2 & 0 \\
\hline 9 & 6750 & 0 & 0 & 16 & 0 & 1 \\
\hline Total & $49,738.7$ & 254.3 & 16 & 0 & 0 & 0 \\
\hline
\end{tabular}

Source: Analysis by Makassar Archaeology office in 2014.
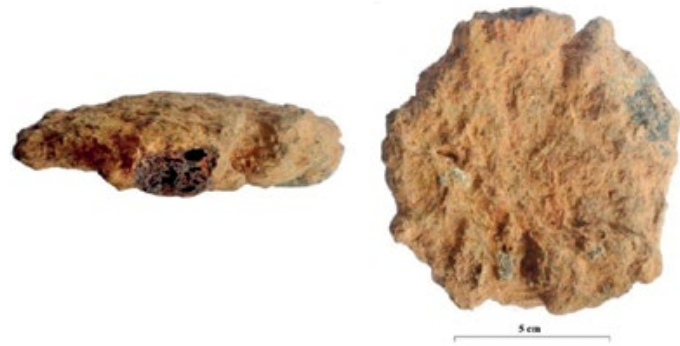

Figure 13.10: Iron slag found in Spit 9 in the T2S1 square.

Source: The authors.
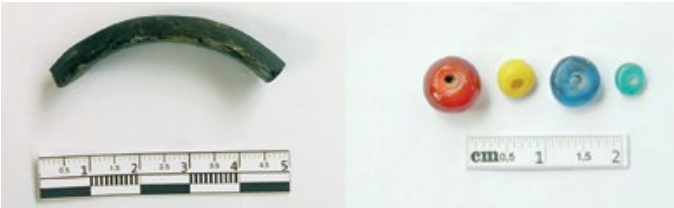

Figure 13.11: Glass bracelet fragment found in Spit 7 in the T2S1 square (left), and glass beads found in Spit 6 in the B2S1 square (right).

Source: Left: Fakhri et al. (2015:Figure 15): Right: The authors.

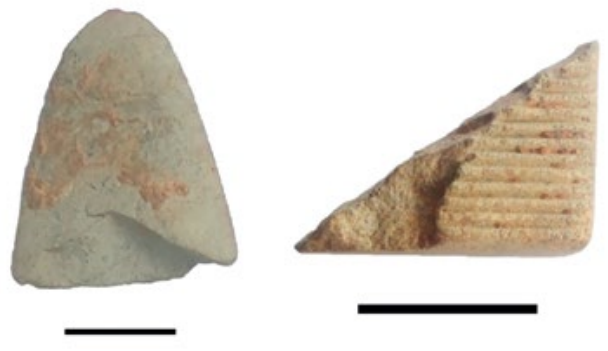

Figure 13.12: Stone adze fragment found in Spit 10 in the T2S1 square (left), and stone barkcloth beater fragment found in Spit 2 in the B3S1 square (right).

Source: Left: Fakhri et al. (2015:Figure 16); Right: The authors.

\section{terra australis 48}


Table 13.3: AMS ${ }^{14} \mathrm{C}$ dates from the T2S1 square at the Sakkarra site (The ANU Radiocarbon Dating Centre).

\begin{tabular}{|l|l|l|l|l|}
\hline Sample code & Dated material & Spit/depth & ${ }^{14}$ C age & Calibrated dates BP \\
\hline S-ANU 39336 & Charcoal & Spit $8(90-100 \mathrm{~cm})$ & 2000 BP & $2062-1867$ \\
\hline S-ANU 39337 & Charcoal & Spit $9(100-110 \mathrm{~cm})$ & $2040 \mathrm{BP}$ & $2123-1895$ \\
\hline
\end{tabular}

Note: Calibration based on Fallon et al. (2010).

Source: Fakhri et al. (2015:Table 4).

\section{Metal and glass artefacts}

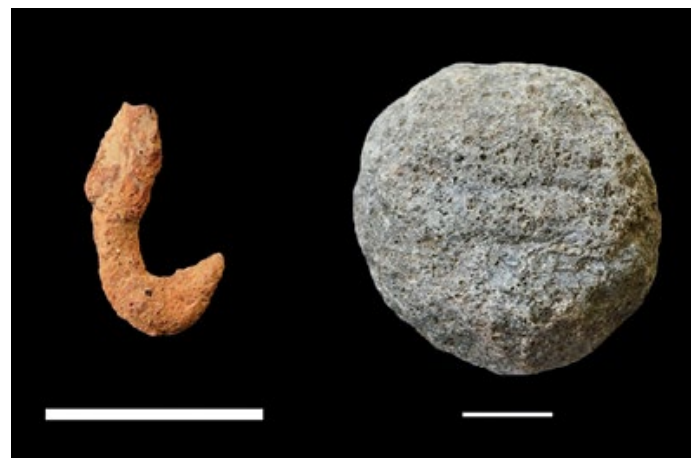

Figure 13.13: Metal artefact in the shape of a fish hook from Spit 3 in the B3S1 square (left) and river pebble with two parallel incisions from Spit 4 in the B2S1 square (right).

Source: The authors.

The metallic artefact found in Spit 3 in the B3S1 square is shaped like a fish hook. It has a maximum length of $2.1 \mathrm{~cm}$ including its corroded surface (see Figure 13.13). In other aspects, Sakkarra appears to resemble the Pantara'an 1 site on the lower Karama River, even though the data have not yet been collected to allow a complete comparison. Anggraeni (2012) notes that the glass beads from Pantara'an 1 are of the 'Indo-Pacific' variety and coloured blue, yellow, green and reddish-brown, similar to the range of colours of the Sakkarra glass beads (Figures 13.4 and 13.11 (right)). She further describes fragments from green glass bracelets and four iron slag fragments excavated at Pantara'an 1, which are artefact categories matched at Sakkarra (Figures 13.10 and 13.11 (left)).

\section{Stone artefacts}

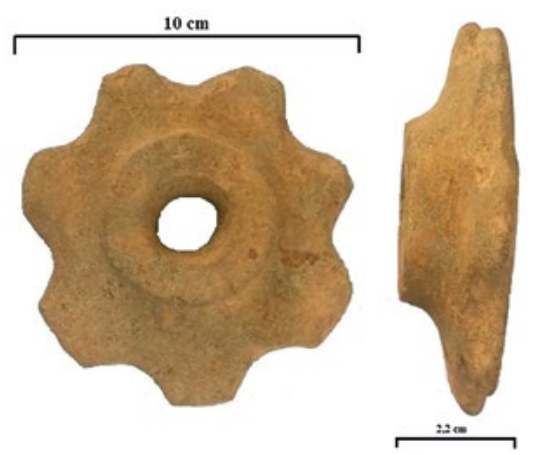

Figure 13.14: Polished stone cog with teeth along its perimeter (square T2S1, Spit 11). Source: Fakhri et al. (2015:Figure 17).

A river pebble from Spit 4 in the B2S1 square has two parallel incisions on one of its faces. The diameter of this pebble is $8 \mathrm{~cm}$ (see Figure 13.13). A similar pebble was excavated at Minanga Sipakko (Simanjuntak et al. 2008:Figures 6-14). The two barkcloth beater fragments from Sakkarra, one from the surface and the second from the T2S1 square (Figures 13.4 and 13.12), indicate a rectangular shape and deep grooves on the working surface, as recorded for the Karama River barkcloth beaters (Hasanuddin, this volume).

The majority of the excavated ground stone artefacts are adze fragments (e.g. Figure 13.12). An exception is the sandstone artefact from Spit 11 in T2S1, which is shaped like a mace head (Figure 13.14). This artefact has a diameter of about $9.5 \mathrm{~cm}$ and is a cog stone with seven symmetrical teeth around its perimeter. There is a central hole of $2.3 \mathrm{~cm}$ diameter, and a central boss on one face that looks like it could have held a rod for manipulating the cog stone. The complex symmetry of this sandstone artefact points to an advanced ability in grinding stone. Its function is not yet clearly determined, but one possibility is its use in smelting metal. 


\section{Pottery}

The total quantity of earthenware from the two test excavations amounted to 8488 sherds. These were predominantly body sherds $(\mathrm{n}=7415,87.4 \%)$, supplemented by rim sherds $(\mathrm{n}=1027$, $12.1 \%)$, carination sherds $(\mathrm{n}=25,0.3 \%)$, cover sherds $(\mathrm{n}=7,0.1 \%)$, foot-ring sherds $(\mathrm{n}=6,0.1 \%)$, base sherds $(\mathrm{n}=3,<0.1 \%)$, crucible sherds $(\mathrm{n}=2,<0.1 \%)$ and a single handle sherd.

Only 82 of the excavated sherds (1.0\%) are decorated, contrasting with the $99.0 \%(n=8406)$ that are plain. This indicates a low cultural propensity for decorating pottery. Further, just nine sherds show traces of a red slip (0.1\%), contrasting with the $99.9 \%(n=8479)$ that are unslipped. These characteristics also apply to the very late Neolithic pottery at Minanga Sipakko, where over $95 \%$ of the pottery in the uppermost habitation spits was plain and unslipped, and only a small percentage either decorated or red-slipped (Anggraeni et al. 2014:Figure 3).

At Sakkarra, only body sherds appear to have been decorated. The observed motifs include stamped concentric circles, vertically oriented parallel incisions, commas, incised squares (sometimes punctate filled) and diagonal cross-hatching (Figure 13.15). Most of these motifs are broadly matched by motifs recorded for the Minanga Sipakko pottery, less so the motifs recorded at the sites of Latibung (near the mouth of the Karama River) and Kamansi (Table 13.4). However, it is unclear which of the highly diverse Minanga Sipakko decorative elements, which included various zigzag, triangular, lunate, arca shell and curvilinear motifs (Prasetyo 2008), persisted through to the late Neolithic, and so the comparisons of

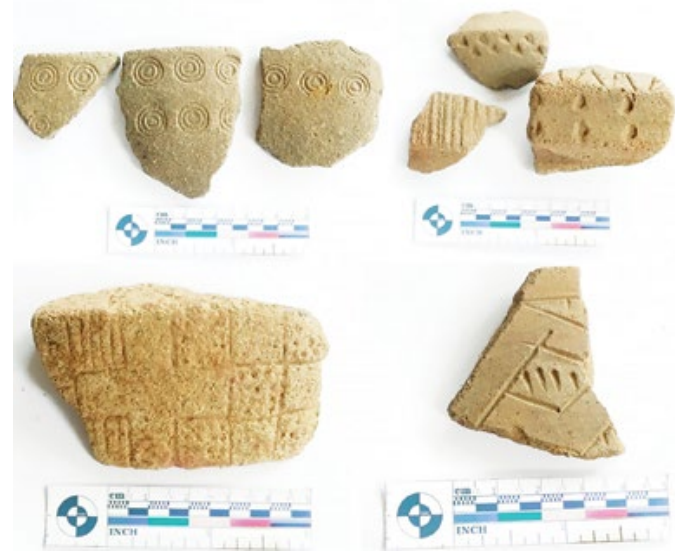

Figure 13.15: Decorated earthenware pottery from the Sakkarra site.

Source: The authors. individual motifs in Table 13.4 is probably of limited diagnostic value.

Table 13.4: Comparison of Sakkara and Karama River pottery decorations.

\begin{tabular}{|l|l|l|l|l|}
\hline Motif & Sakkara & Kamansi & Minanga Sipakko & Latibung \\
\hline Stamped concentric circles & Triple circles & Double circles & Double circles & Single circles only \\
\hline Vertical parallel incisions & Present & Absent & Present & Absent \\
\hline Commas & Present & Absent & Present & Absent \\
\hline Unfilled squares & Present & Square maze & Absent & Absent \\
\hline $\begin{array}{l}\text { Filled square(/rectangle) } \\
\text { motifs }\end{array}$ & $\begin{array}{l}\text { Vertical incisions; } \\
\text { punctate dots }\end{array}$ & Punctate dots & Vertical incisions & $\begin{array}{l}\text { Diagonal incisions with } \\
\text { punctate dots }\end{array}$ \\
\hline Diagonal cross-hatching & Present & Absent & Present & Present \\
\hline
\end{tabular}

Note: Latibung is undated but appears to be an Early Metal Phase site (Anggraeni 2012).

Sources: Sakkara (this chapter); Kamansi, Minanga Sipakko, Latibung (Prasetyo 2008).

A total of 651 sherds could be assigned to a vessel form (Figure 13.16). Cooking pots (periuk) are dominant, accounting for $79.1 \%$ of the identified vessels $(\mathrm{n}=515)$. Bowls (mangkuk) accounted for $15.5 \%(\mathrm{n}=101)$, jambangan jars for $3.4 \%(\mathrm{n}=22)$, large open jars (tempayan) for $1.7 \%$ and kendis for $0.3 \%(\mathrm{n}=2)$. Statistical analysis of the rim diameters (Figure 13.17) indicates that the cooking pots were the most heterogeneous. Their diameters averaged out at $17.7 \mathrm{~cm}(\mathrm{SD}=3.8)$ with a range between 8 and $28 \mathrm{~cm}$. The average rim diameter of the bowls was $20.0 \mathrm{~cm}(\mathrm{SD}=3.1)$ 
and the range was 12 to $24 \mathrm{~cm}$. The jambangan jars had an average rim diameter of $27.4 \mathrm{~cm}$ $(\mathrm{SD}=2.2)$, ranging between 26 and $34 \mathrm{~cm}$. The tempayan jars had the largest diameters overall, with an average of $33.3 \mathrm{~cm}(\mathrm{SD}=4.7)$ and a range between $28 \mathrm{~cm}$ and $40 \mathrm{~cm}$. The kendis had the smallest rim diameters, with an average of just $4 \mathrm{~cm}$.

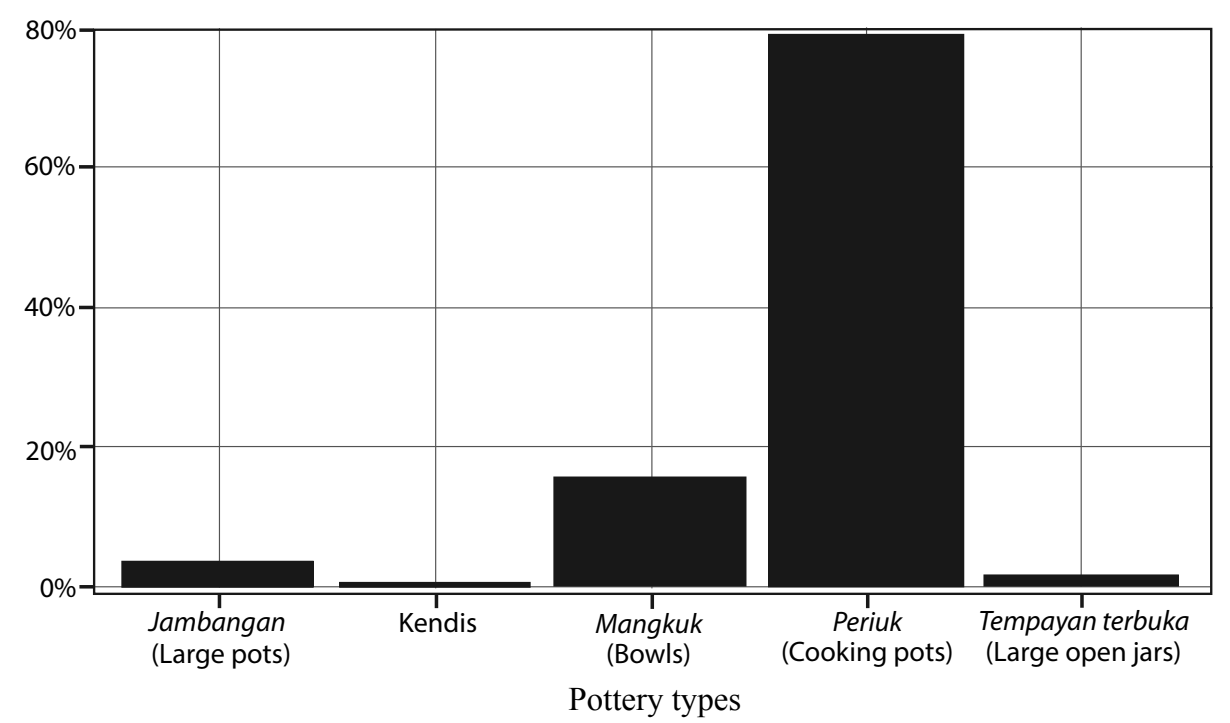

Figure 13.16: Percentages of pottery vessel form based on analysis of rim sherds. Source: The authors.

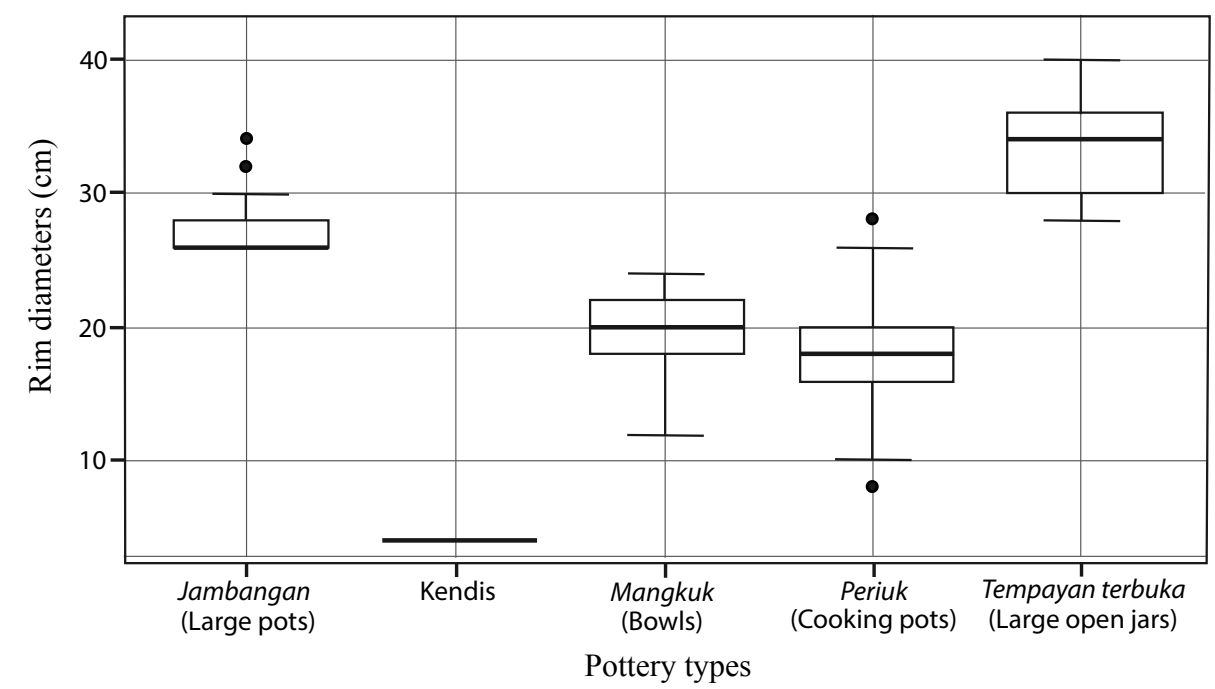

Figure 13.17: Box plot diagram of the distribution of the vessels' rim diameters.

Source: The authors.

The cooking pots showed the greatest variety of rim types. Figure 13.18 illustrates the six rim types observed for cooking pots and the three rim types observed for bowls. Type A cooking pots were the most frequently recorded type ( $\mathrm{n}=398,77.3 \%$ of cooking pots). Type B cooking pots accounted for $17.7 \%(\mathrm{n}=91)$, Type C for $0.2 \%(\mathrm{n}=1)$, Type D for $1.6 \%(\mathrm{n}=8)$, Type E for $2.5 \%$ $(\mathrm{n}=13)$ and Type $\mathrm{F}$ for $0.8 \%(\mathrm{n}=4)$. As for the bowls, the Type A variant was the most frequently recorded, accounting for $90.1 \%$ of bowls $(n=91)$. The rarer variants were the Type $B(n=8,7.9 \%)$ and Type $\mathrm{C}$ bowls ( $\mathrm{n}=2,2.0 \%)$. 


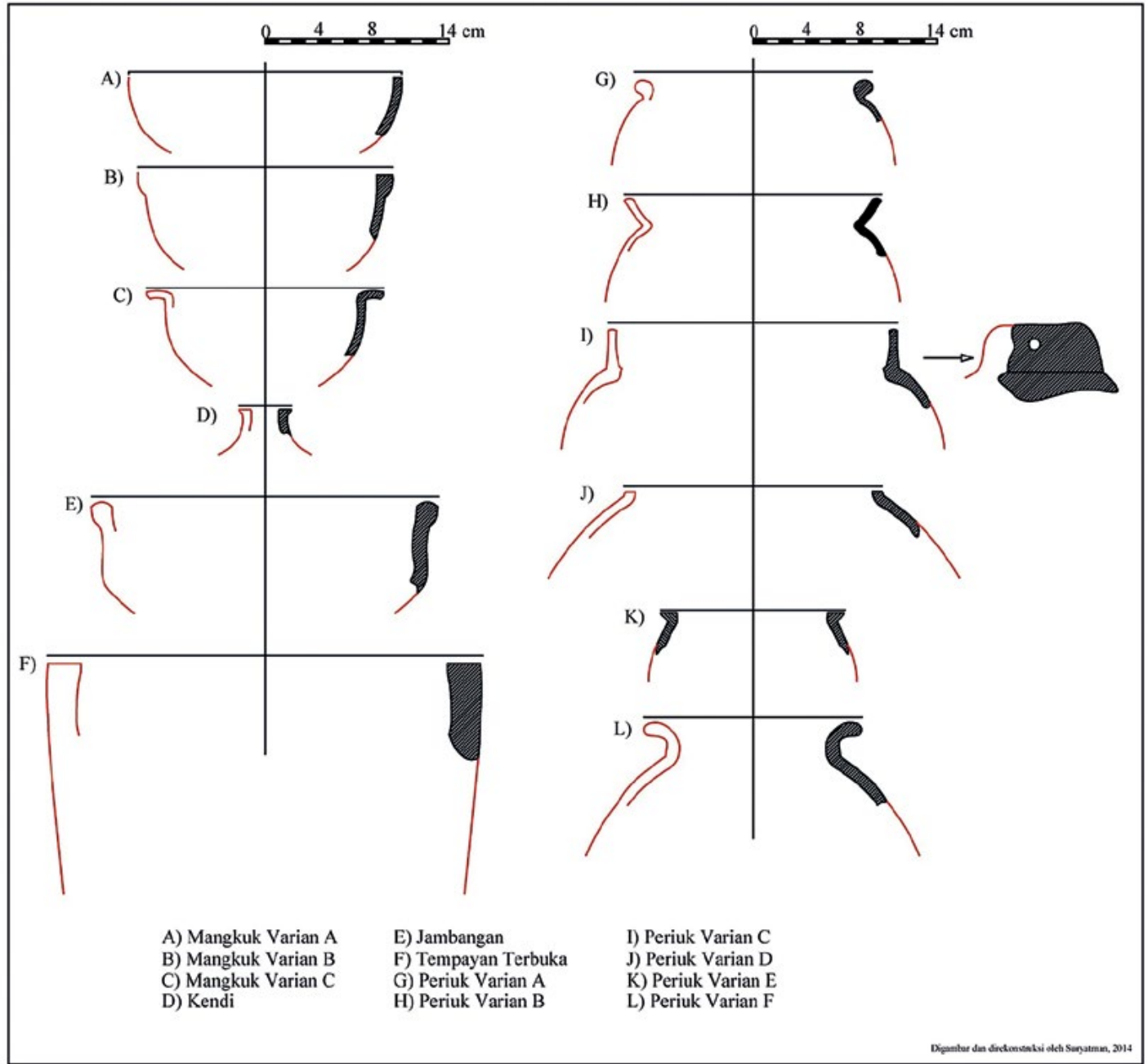

Figure 13.18: Reconstruction of the earthenware vessel forms at the Sakkarra site based on rim analysis. The vessel types are scaled to each other based on their average recorded diameters. Source: Fakhri et al. (2015:Figure 18).

The Sakkarra rim shapes show few similarities with the rim shapes from Kamansi, Minanga Sipakko and Pantara'an 1 (Anggraeni et al. 2014:Figures 13.5 and 13.6). Only the Sakkarra 'Cooking Pot Type E' rim shape (Kin Figure 13.18) is also documented for all of Kamansi, Minanga Sipakko and Pantara'an 1. The only other apparent similarities are between the Sakkarra 'Bowl Type A' and 'Cooking Pot Type C' rim shapes (A and I in Figure 13.18), which are respectively matched by early Neolithic rims from Minanga Sipakko and Kamansi.

\section{Discussion and comparisons}

The ability to use and manipulate metals is one of the major technological advances for prehistoric human societies, and Sulawesi has much to contribute to the understanding of the technological transition from the Neolithic to the Metal Phase. The research findings from the Sakkarra site show that the Karama drainage region was already occupied by prehistoric Austronesian speakers when the practice of metal smelting came to the region at around 2000 BP. 
The results of research undertaken to date show that there were four phases of occupation by Austronesian speakers in the Karama drainage area. The first phase is believed to have begun at least $3500 \mathrm{BP}$, when Austronesian speakers began to colonise the Sulawesi interior via the Karama drainage and introduce their early Neolithic traditions. Fine, red-slipped pottery was the signature of this phase in the Kalumpang area, associated with bone points, adzes (some pierced), haematite, grindstones, whetstones, ornamental pendants of green stone (but not nephrite), fragments of limestone bracelets and various shell artefacts (Hakim and Suryatman 2012; Simanjuntak et al. 2007, 2016). Similarly, several other sites contain red-slipped pottery in their early settlement phases, including the Dimolit site in the Philippines, which, probably dating to 4500-3500 BP, may be the earliest in ISEA (Bellwood 2000). Also, the Bukit Tengkorak site in Sabah contained red-slipped pottery during its initial occupation (Chia 2003).

The second phase in the Kalumpang area began at around 3000 BP. The fine pottery of the first phase was replaced by coarse, low-fired ware and dwindling application of a red slip. Some of the vessels were found to be decorated at this time, although the proportion of decorated sherds (at Minanga Sipakko) also dwindled during the late Neolithic. The research by Simanjuntak et al. (2007) at Minanga Sipakko and by Hakim and Suryatman (2012) at Kamansi shows that obsidian artefacts belong to this second phase. The Kamansi excavations also indicate a notable increase in the quantity of pottery during the second phase, reflecting an increase in the use of pottery vessels and perhaps as well in the population size in the Kalumpang area. Population pressure may also have resulted in the establishment of new settlements in the Karama area. Occupation at the Pantara'an 1 site, which lies closer to the coast, evidently commenced during this second phase (Anggraeni et al. 2014).

The third phase, denoting the transition from the Neolithic to the Metal Phase, is thought to have commenced before 2000 BP. This phase might be represented by Pantara'an 1 with its earthenware sherds and associated metal artefacts, iron slag and glass beads, dating to after $2500 \mathrm{BP}$, some but not all of which can be related to jar burials at the site (Anggraeni 2012). Neolithic technology did not disappear with the early use of metals. This can be seen in the various polished stone artefacts from Pantara'an 1 such as adzes (one from the main jar burial), which perhaps were still important for agricultural activities.

The fourth phase is thought to have already been underway by $2000 \mathrm{BP}$. The fieldwork at the Sakkara site recovered traces of this fourth occupation phase in the southern hinterland of the Karama drainage area. The technology of smelting metals was established by then, but Neolithic traditions still persisted. This is demonstrated by the various stone adze fragments excavated at Sakkarra, the fragments of barkcloth beaters similar to the Karama River barkcloth beaters, and in particular the symmetrically toothed cog stone, which displays remarkably adept skills in polishing stone. Its function is not clear, but it may have been used in smelting metal. The earthenware pottery was generally undistinguished, as shown by the low proportion of sherds with decorations $(1.0 \%)$ or a red slip $(0.1 \%)$, similar to the very late Neolithic pottery at Minanga Sipakko. However, rim comparisons tend to distinguish the Sakkara pottery from the pottery at Minanga Sipakko as well as other Karama Rivers sites.

Investigations into the prehistory of the Karama drainage portray a picture of cultural development between the Neolithic (3500 BP) and the Metal Phase (2000 BP). The development of metallurgy did not lead to the loss of polished stone technology in the Karama drainage area, which was still present 2000 years ago, as shown at the Sakkara site.

Unfortunately, the Sakkarra site is currently under considerable threat from the potential of further gold mining. Though mining has ceased for the time being, there is still a contractual mining period of a further five years. The second threat is erosion by the Bonehau River, which 
is slowly eroding away the bank and the contained site deposits. Further research incorporating a combination of scientific disciplines and techniques at the Sakkarra site is necessary in order to gain a more comprehensive picture of the cultural developments of its prehistoric inhabitants.

\section{Conclusions}

The Sakkarra site plays an important role in reconstructing the cultural developments of prehistoric Austronesian speakers during the Early Metal Phase both in Sulawesi and in ISEA more generally. Colonisation of the Sakkarra site can be reasonably traced back to the Neolithic occupation of the Karama River, which lies a short distance to the north. Cultural continuity is reflected in the maintenance of Neolithic technological traditions such as the manufacture of earthenware pottery and polished stone tools. On the other hand, the appearance of glass and iron artefacts (at Pantara'an 1 as well Sakkarra) heralds the introduction of new cultural influences on the Karama drainage inhabitants. The pottery rim shapes at Sakkarra are dissimilar from those at the Karama River Neolithic sites, but, in the current state of research, it is unclear whether these dissimilarities reflect introduced, Early Metal Phase cultural influences or local cultural change. Certainly, the polished cog stone is difficult to ascribe to external influence because examples of this tool type do not appear to have been documented from other sites. Thus, the example of Sakkarra suggests that the Neolithic to Metal Phase transition involved continuity of Neolithic technology but with scope for local innovation, along with the capacity to absorb metallurgy and participate in the growing trade in glass and other exotic items.

\section{Author biographies}

Suryatman Makassar Archaeology Office, Makassar, South Sulawesi, Indonesia

Budianto Hakim Makassar Archaeology Office, Makassar, South Sulawesi, Indonesia

Fakhri Makassar Archaeology Office, Makassar, South Sulawesi, Indonesia

\section{References}

Anggraeni. 2012. The Austronesian Migration Hypothesis as seen from Prehistoric Settlements on the Karama River, Mamuju, West Sulawesi. Unpublished PhD thesis, School of Archaeology and Anthropology, The Australian National University, Canberra.

Anggraeni, T. Simanjuntak, P. Bellwood and P. Piper. 2014. Neolithic foundations in the Karama valley, West Sulawesi, Indonesia. Antiquity 88(341):740-756, doi.org/10.1017/S0003598X00050663 (accessed 5 June 2018).

Bellwood, P. 2000. Prasejarah Kepulauan Indo-Malaysia (Prehistory of the Indo-Malaysian Archipelago). (Translated by D. Tanudirjo). Jakarta: PT Gramedia Pustaka Utama.

Bellwood, P. 2017. First Islanders: Prehistory and Human Migration in Island Southeast Asia. Oxford: Wiley Blackwell. doi.org/10.1002/9781119251583 (accessed 5 June 2018).

Chia, S.M.S. 2003. The Prehistory of Bukit Tengkorak as a Major Pottery Making Site in Southeast Asia. Kota Kinabalu: Department of Sabah Museum.

Fakhri, Suryatman, B. Hakim and R. Sardi. 2015. Exploration of prehistoric sites in the Karama watershed, West Sulawesi, Indonesia. Journal of Indo-Pacific Archaeology 39:18-25. journals.lib.washington.edu/ index.php/JIPA/article/view/14786/12489 (accessed 5 June 2018). 
Fallon, S.J., L.K. Fifield and J.M. Chappell. 2010. The next chapter in radiocarbon dating at The Australian National University: Status report on the single stage AMS. Nuclear Instruments and Methods in Physics Research Section B: Beam Interactions with Materials and Atoms 268(7-8):898-901. doi.org/10.1016/j. nimb.2009.10.059 (accessed 5 June 2018).

Hakim, B. and Suryatman. 2012. Eksistensi Penutur Austronesia di Situs Kamansi. Unpublished Report. Makassar: Balai Arkeologi Makassar.

Hasanuddin. 2018. Prehistoric sites in Enrekang Kabupaten, South Sulawesi. In S. O'Connor, D. Bulbeck and J. Meyer (eds), The Archaeology of Sulawesi: Current Research on the Pleistocene to the Historic Period, pp. 171-190. Canberra: ANU Press.

Morwood, M., I. Mahmud and T. Simanjuntak. 2007. Penelitian situs Minanga Sipakko dan sekitarnya. In T. Simanjuntak, F.S. Intan and I. Mahmud (eds), Kalumpang: Arkeologi dan Etnografi, pp. 46-53. Jakarta: Pusat Penelitian dan Pengembangan Arkeologi Nasional.

Prasetyo, B. 2008. Pottery from the Neolithic sites at the banks of Karama River. In T. Simanjuntak (ed.), Austronesian in Sulawesi, pp. 77-92. Jakarta: Center for Prehistoric and Austronesian Studies.

Simanjuntak, T. 1994. Kalumpang: Hunian tepi Sungai bercorak Neolitik-Paleometalik di Pedalaman Sulawesi Selatan. Aspek-aspek Arkeologi Indonesia No. 17. Jakarta: Pusat Penelitian dan Pengembangan Arkeologi Nasional.

Simanjuntak, T. 2015. Progres penelitian Austronesia di Nusantara. Jurnal Amerta 33 (1):1-76. doi.org/ 10.24832/amt.v33i1.211 (accessed 5 June 2018).

Simanjuntak, T., F.S. Intan and I. Mahmud (eds). 2007. Kalumpang: Arkeologi dan Etnografi. Jakarta: Pusat Penelitian dan Pengembangan Arkeologi Nasional.

Simanjuntak, T., M.J. Morwood, F.S. Intan, I. Mahmud, K. Grant, N. Somba, B. Akw and D.W. Utomo. 2008. Minanga Sipakko and the Neolithic of the Karama River. In T. Simanjuntak (ed.), Austronesian in Sulawesi, pp. 57-75. Jakarta: Center for Prehistoric and Austronesian Studies.

Simanjuntak, T., A.A Oktaviana and R. Handini. 2016. Updated views on the Austronesian studies in Indonesia. In B. Prasetyo, T.S. Nastiti and T. Simanjuntak (eds), Austonesian Diaspora: A New Perspective, pp. 207-222. Yogyakarta: Gadjah Mada University Press.

van Stein Callenfels, P.V. 1951. Prehistoric sites on the Karama River. Journal of East Asiatic Studies 1(1):82-93. 
This text is taken from The Archaeology of Sulawesi: Current Research on the Pleistocene to the Historic Period, edited by Sue O'Connor, David Bulbeck and Juliet Meyer, published 2018 by ANU Press, The Australian National University, Canberra, Australia.

doi.org/10.22459/TA48.11.2018.13 